\title{
From Pest to Pet: Liminality, Domestication and Animal Agency in the Killing of Rats and Cats
}

\author{
NORA SCHUURMAN \\ School of History, Culture and Arts Studies \\ University of Turku, Finland \\ nora.schuurman@utu.fi \\ KARIN DIRKE \\ Department of Culture and Aesthetics \\ Stockholm University, Sweden \\ karin.dirke@idehist.su.se
}

\begin{abstract}
The ways in which the end of life of an animal is understood and undertaken depend on the category of the animal and its position in relation to humans. In this paper, we explore how transformations in human-animal relationality, including practices and cultural conceptions about animals, become apparent in the norms and practices regarding the killing of animals. We focus here on rats and cats, species whose position in society has always been liminal, especially between the category of pet and that of pest but also between wild and domesticated. Rats and cats have co-existed with each other and with humans since a very long time and the three species have co-evolved in a constant dance of mutual interests and conflicts. The shared history of this multispecies network reflects in many ways how humans have related to animals in different historical and spatial contexts and how these relations have transformed. By discussing the entanglement of rats, cats and humans in the close connection between caring and killing we wish to highlight the ways in which human-animal relations are manifested in the North of Europe during the 20th century. The specific context of the study is Sweden and Finland, countries that share similar histories and cultural characteristics. In our analysis we draw from various data collected in both countries, including written narratives from an nationwide writing collection and historic documents such as the journals of animal welfare societies and documents concerning the extermination of rats.
\end{abstract}

KEYWORDS: animal death; liminality; domestication; Sweden; Finland 


\section{Introduction}

In the beginning of WWII, the relational network involving the rat, the cat and the human became very apparent in an event conveyed by historian Hilda Kean (2017). The residents of London were told that the safest place for companion animals would be with their human owners. Still, many killed their pets in fear of not being able to take them to the shelter with them. This resulted in a situation where rodents started spreading beyond control and authorities had to emphasize the need for residents not to kill any more cats (or dogs).

The story points to the ever-changing relations between rats, cats and humans. Of all the animal species whose position has transformed as a consequence of the new sensibilities towards animals since the late 19th century, two of the most interesting are probably the rat and the cat. While they have been regarded and treated in different ways in different spatial and temporal contexts, they have largely remained in the margins of academic exploration (for exceptions see Beumer 2014; Holmberg 2015).

For about 4000 years, starting in ancient Egypt, cats have been kept for the primary purpose of controlling rodents in human spaces (Rogers 2006, 14; Holmberg $2015,47)$. In a sense, the task of killing one animal species has been given to another species, and in this arrangement cats have acted as non-human 'contract killers'. This autonomous role in which feline agency has not been particularly restricted, has contributed to the conceptions of cats as independent, sly, somewhat unreliable, and even associated with witches (Rogers 2006, 27; Holmberg 2015, 48). It has also affected the human-cat relationship and the treatment of cats, including their killing. The cat has only upheld the status of a pet for the last 300 years and even more recently acquired the position of an animal that merits humane treatment (Rogers 2006, 10, 48). Today, cats have become the most popular pet in the EU, outnumbering dogs (Statista 2019).

The brown rat, Rattus norvegicus, was a rather late arrival on European soil. Though its history remains contested, it seems to have replaced the black rat as the main adversary of the cat by Early Modern times (Benedictow 2010, 73-74; Bjärvall \& Ullström 1985, 106-108). The rat developed a niche around urban settings. It thrived off human waste and kept warm close to domesticated animals such as pigs and cattle. In this way, the rat uses the human as a host animal. Rats appeared in laboratories around the 1850's and have remained one of the most favored animal species used for experimentation. The pet rat, or fancy rat, is closely related to laboratory rats. Laboratory rats were bred to become less aggressive and easier to handle, however, laboratory rats released in the wild can quickly adapt and flourish and thus do not differ 
significantly from their wild ancestors (Schipani 2019). Recent research on rats, widely disseminated in media, has highlighted the animals' positive interaction with humans, such as its joy when tickled (Ishiyama \& Brecht 2016) or its playfulness (Reinhold et al 2019).

The history and current emotions and practices associated with the rat and the cat reflect the many ways in which humans have related to animals in different historical and spatial contexts and how these relations have transformed. Rats and cats share a common history, in which humans have interfered in different ways, leading to the gradual development of a specific set of conceptions and practices for each species. One of the transforming practices that aptly illustrates the roles of the rat and the cat in society is that of killing them.

This article explores the entanglement of these three species, as well as the close connection between caring and killing. By discussing the avenues by which the killing of these animals has been negotiated in Nordic societies we wish to highlight the ways in which human-animal relations are manifested in 20th century Finland and Sweden, countries that share similar history and cultural characteristics. In our analysis we draw from various data collected in both countries, including written narratives from a nationwide writing collection and historic documents such as the journals of animal welfare societies and documents concerning the extermination of rats.

In human-animal studies, focusing on the relations between different nonhuman species as they have been influenced by humans adds to the recent, prolific work carried out on the relations between humans and single species. Such studies have thus far been rather sparse. In a field whose focus is on the myriad ways in which humans have affected, exploited, transformed and interacted with other species, it is surprising that there has not been more interest in exploring the positions of different non-human species and how they affect each other in multispecies networks. This study, in its part, is an attempt at filling this gap. By using the concept of liminality as an analytical tool we will show how two different species - the cat and the rat - relate, transgress and challenge each other's position in relation to humans. Through an analysis of the norms and practices of killing and grieving for these two species, we aim to shed light on how their position becomes destabilized as modern life develops in the Nordic countries. The study also contributes to the discussion on biopolitics in terms of determining who is allowed to live and who is killed so that others can live (see e.g. Redmalm 2019). 


\section{Liminality, domestication and the killing of animals}

The ways in which the end of life of an animal is understood and undertaken depend on the category of the animal and its position in relation to humans (Leach 1964; Cartmill 1993; Marvin 2006). Transformations in human-animal relationality, including practices and cultural conceptions about animals, become apparent in the norms and practices regarding the killing of animals. Rats and cats are species whose position in society have always been liminal, especially between the category of a pet and that of a pest, but also between wild and domesticated. These two species have co-existed with each other and with humans since a very long time and the three species have coevolved in a dance of mutual interests and conflicts (see Haraway 2008). As individuals as well as species, cats and rats have been configured in relation to humans in different ways.

In this article, liminality is defined as the property of being fluid between categories such as wild-domestic, natural-cultural, useless-useful, urban-rural, or killable-nonkillable (Wischermann et al. 2018, 4). Not only can the animal occupy a liminal position but it seems itself to be able to become hybrid, to fluctuate between categories (Wischermann et al. 2018, 5). We argue that as the positions of rats and cats have become increasingly liminal, the animals have become fluid - they have acquired the ability to fluctuate between the category of pest and pet. Central to this fluctuation is the agency of the animal, which thus becomes visible through the animal's categorical liminality. The norms, conceptions and practices of killing rats and cats in different historical contexts are related to their liminal position between wildness and domestication (Power 2008) and the different categories in which they are placed.

In order to understand changes in human-animal relations, we turn attention to the cultural practice of categorizing animals according to their relationship - and usefulness - to humans (Arluke \& Sanders 1996). Both rats and cats have been categorized in different ways according to the animals' relationship to humans and to each other domesticated, homeless, feral - and to place: house, farm, city, laboratory (Holmberg 2015, 47; Beumer 2014). Similarly, to many other animals, including for example the pigeon (Jerolmack 2008) and the squirrel (Crowley et al. 2018), these varying categorizations impact on their killability. Central to these categorizations is the concept of domestication.

The word 'domestic' refers to the house or household, and 'domestication' can thus be understood as family members or servants becoming accustomed or belonging to the household (Bulliet 2005, 40; Cassidy 2007, 5; Russell 2007, 28). There are several understandings of the concept, partly depending on disciplinary focus. In 
biology, domestication in animals primarily involves genetic changes brought about by animal husbandry, whereas in the social sciences emphasis has been on the relations between humans and animals, especially on their emerging status as property (Russell 2007,30 ). Historic scholarship has focused on the effects of domestication in terms of spreading of disease and the human interest in breeding as well as hybrids (Ritvo 2010). In addition to different approaches, studies of domestication have contributed to the dichotomy of the 'wild' and the 'domestic', which is seen as increasingly problematic (Ingold 1994, 11-12). This is partly due to the inherent liminality of domestication: the same animal can be at times perceived as domesticated and subjected to control and care by humans and at other times as natural and in need of minimal care (Franklin \& Schuurman 2017). Such fluctuation is also evident in the cases of 'wild' animals kept as pets or game animals that are defined as property of the state (Russell 2007, 30).

As Whatmore \& Thorne $(1998,435-436)$ note, the category of wildness is a question of space, with wild animals often imagined in unpopulated landscapes at a distance from humans, instead of human societies and spaces. The rat, for instance, has long since become a species living in very close proximity to humans, and yet its transformation to pet is comparatively late and related to its history as a laboratory animal. The history of the cat is slightly different and it is perhaps to a greater extent provided with a magical meaning, being the animal associated with witches and sorcery (Broberg 2004, 32-39; Rogers 2006). The category of domestication also changes the relations between cats and rats. Domesticated cats have become more than predators as they are perceived as tools for exterminating rats and can even be listed among technologies useful to kill rats (Broberg 2004, 114). The predatory actions of the cat are increasingly viewed as a problem for wildlife, especially birds, while domesticated rats cease to be prey for cats and are displayed as companions to both humans and cats. (A Google-search on videos [November 8, 2018] provides over 300000 results regarding "cats and rats playing", while "cats and rats fighting" receives merely 58 400.) Further, cats and rats are considered similar to humans in the sense that neither are considered to be edible in the Western context (Leach 1964).

Both rats and cats seem to uphold a liminal position in relation to each other as well as in relation to humans. Rats refuse categorization as entirely wild animals and cats are not always considered fully domesticated. For both species, their shared history with humans cannot be depicted in terms of the traditional definition of domestication as relying on selective breeding. It can rather be understood as coevolution, a slow process where any breeding selection has, until very recently, been unconscious at best (Leach 2003). These two species, therefore, aptly illustrate the liminal nature of 
domestication: one of between-ness and transition (Herman \& Yarwood 2014).

To further the discussion between different approaches to domestication, Russell (2007) proposes focusing the study on various kinds of human-animal relationships and different practices that create domestication and wildness, especially in situations and environments where they overlap. As Haraway $(2008,80)$ notes, all animals except humans can be killed without the understanding that they are actually "murdered", describing what Despret $(2016,83)$ terms an 'ontological rupture' between humans and animals, preventing the possibility of thinking their deaths together.

As Russell $(2007,35)$ points out, "all domestic animals complicate the boundaries between humans and animals, nature and culture." Cultural conceptions of killing act as a tool for enforcing the human-animal boundary, as is seen in abattoirs and laboratories around the world on a daily basis. In some instances, however, the rules and norms concerning the killing of certain animals reflect the ambiguity of human relations with animals and consequently contribute to the transgressing and dissolving of the boundary. This is the case with pets, animals that are so close to humans that they can be argued to occupy a liminal position in society, fluctuating between culture and nature (Charles \& Davies 2011). It is also a consequence of the liminality of the animal itself, its ability to move between positions. In Western societies, the killing of pets is only accepted in situations where, due to illness, old age or serious behavioural issues, the life of the pet cannot be continued anymore. In shelters, many pets are euthanized as surplus animals, but the general acceptance of this practice is questionable (see e.g. Arluke \& Sanders 1996).

Recently, domestication has been explored as a shared process between humans and non-human animals (Cassidy 2007), or as a form of kinship (Russell 2007, 28). Power (2012) understands domestication in animals living in close contact with humans as a relationship embedded in human culture and practices, including encounters with and categorizations of animals. It is neither a stable relation nor an event occurring in distant prehistory but an ongoing process, following development in the practices of keeping these animals "continuously negotiated and held in place" (Power 2012, 371).

These practices have also challenged, in some contexts more than others, the agency of the animals in question. By animal agency we mean that the actions of the animal are intentional and have meaning for the animal itself, observed, interpreted and understood by humans in different ways in different contexts (Crist 1999, 2-3). The agency of an animal also includes subjective experiences and feelings that are characteristic to the individual animal (McFarland \& Hediger 2009). Animal agency is relational in that it shapes human action as well as relations between humans and 
animals (Charles \& Davies 2011). Both cats and rats, historically and presently, display agency in relation to humans - they both live relatively independently close to humans. Domestication means control, yet both cats and rats have proved to be rather difficult to control.

\section{Data and methods}

The materials analysed for this article consist in a mixture of different types of data. The historic documents used, are collected from the Royal Library in Sweden where journals from the animal welfare movement in Sweden, as well as documents - such as brochures and accounts - concerning the 20th century attempts to exterminate rats, are kept.

In addition to the documents, we have analysed written narratives collected in a nationwide writing collection The cat, the dog, and the horse - the animal as a family member, organized by the Folklore Archives of the Finnish Literature Society (SKS) in 2014-2015. In Finland, the method is used widely by scholars of different disciplines to collect experiential knowledge of daily life in written form on any given topic. Narratives collected in writing collections are typically autobiographical (Latvala \& Laurén 2013). Autobiographical narratives about human-animal relations can be used to explore shared experiences between the human and the animal, and the cultural meanings given to them (Leinonen 2013,67). Autobiographical narratives focus on the personal experiences of the authors, but they also allow non-human agency to emerge in the ways in which authors recount their own perceptions and interpretations of their pets' actions and feelings (Power 2008). In experiential narratives such as the ones analyzed in this paper, the authors reflect on their own life events and experiences in a way that makes sense to themselves (Latvala \& Laurén 2013). Narrated experiences are part of cultural meaning-making as they provide access to past experiences by giving them meanings in the present. They thereby assist in understanding temporality and change.

The writing collection was announced in Finnish magazines and social media. People were encouraged to write about their memories and experiences of sharing their life with pets, including experiences of animal death. One of us (Schuurman) was personally involved in designing the themes for the collection. For the collection, 190 narratives were received, consisting of 1076 pages. From this material, 49 narratives included descriptions of feline death. The writing collection data was analysed thematically.

Our aim in combining different types of data, instead of direct comparisons, is 
to bring together different events and experiences in order to illustrate the contextual transformations in rat-cat-human relationality in the Nordic countries. In the following sections, we explore the transforming positions of the cat and the rat: the cultural conceptions, norms and practices of killing, the role of agency and control in domestication and the centrality of care in the current practices of killing rats and cats.

\section{Controlled killing and killing to control}

\section{1 The early animal welfare movement}

The norms and conceptions regarding when and how a pet can be killed differ over time and in relation to species. The killing of pet animals became institutionalized with the establishment of animal welfare movements in the West, during the latter half of the 19th century and early 20th century. The common practices of killing animals, pets as well as animals produced for human consumption, were considered inappropriate and cruel. In Sweden the Women's animal welfare society offered a euthanizing service, staffed by veterinarians from the beginning of the 20th century to humanely dispose of unwanted pets (Dirke 2000, 202). Similar practices were introduced in Finland, also by women active in the animal welfare movement (Nieminen 2001, 107).

The death of animals was widely discussed in the animal welfare societies during the 19th century. Euthanasia was, at the time, the center of animal ethics. Killing animals could be described as the main measure of relieving them of pain, according to the progressive welfare movement. The societies focused on quickly putting suffering animals down, whether it was work horses, farm animals or pets (Dirke 2000, 201). In Sweden the women's society for the protection of animals took the lead in professionalizing the killing of domestic animals by organizing courses and distributing information about how to humanely kill animals (Annual report of the Swedish women's association for the protection of animals $1888,3-4)$. In the case of farm animals, the rationality of killing humanely was stressed and concerning slaughter, the society pointed out the benefits - such as meat of higher quality - of a painless death for animals (Djurvännen 1880,62 ). The animal protectionists did not strive to eliminate the killing of animals but to make sure it was performed professionally, and with a minimum of pain for the animal (Svärd 2015, 258). From the animal welfare point of view, the stunning of animals before killing them was most important. For this effect technology was developed and tested by the animal welfare societies. The animal welfare journals published results from the experiments as well as drawings of killing apparatuses (Djurvännen 1887:5, 


\section{7, 1888:4, 26-27; Djurvännernas Tidning 1890:4, 57-58).}

In 1899 the women's society for the protection of animals opened an institution for killing pets (Annual report 1900, 12). The establishment quickly became popular among the general public, according to its own reports. During its first year about 700 cats, dogs and other small animals were killed in the establishment (Annual report $1902,11-12$ ). The killing of the animals was supervised by a veterinarian and the methods used were carefully discussed. Technological innovations, with the purpose of distancing humans from killing, were tested continuously (Annual report 1905, 13; Dirke $2000,202)$. At the same time, the measures used for exterminating rats were equally distancing: filling colonial trade ships with gas or distributing poison throughout cities (Nilsson 1904, 1; Gezelius 1911, 44; Regnér 1928, 9).

The animal welfare movement was generally not particularly upset about the death of animals. If they were killed swiftly and painlessly this was to be preferred to keeping them alive. Svärd $(2015,219)$ has convincingly argued that the problem of killing animals was construed in a way which made it possible to eliminate the inhumane treatment of animals while continuing the overall exploitation of them in society. Thus, during the 20th century the killing of cats was set within an ethical framework that made them killable - although the killing was to be done responsibly (Haraway 2008, 81).

\section{2 Controlling rats}

Rats have been pursued since times immemorial and were hated long before they were associated with city sours (Burt 2006, 9). Early on, rats were linked to disease, even though the exact mechanisms of the infection were not known. It was noted that outbreaks of sickness were often foreboded by rats dying in great numbers. Burt (2006) points to how the rat became more directly linked to the spreading of disease from the end of the 19th century onwards. An important cause of the strong linkage between rats and human disease was probably the most recent plague epidemic, which began in 1894. Rats arriving on ships sailing the colonial trade routes were at first thought to bring the disease (Burt 2006, 17). It was soon discovered that the true vectors were the fleas on the rats, however, rats were easier to exterminate than fleas.

Plague is a disease which evokes terror in the collective mind of the western world. It is not only a human catastrophe but a metaphor for disaster and deterioration of the modern world (Echenberg 2007, 4-5). Any disease spread by animals, such as rabies, plague or more recently avian flu, somehow seems more sinister, disastrous and uncontrollable than other illnesses. The fear of the bubonic plague - an iconic and 
terrifying disease to the European mind - made the rat appear as a killer rodent, threatening modern life with a medieval infection. Before that rats were unwanted because they were considered to steal human resources, but not obviously associated with the spreading of disease. For centuries, rats - along with mice - had been controlled by cats, both in rural and urban environments (see e.g. Kean 2017, 37), creating a peculiar relation between the two species, designed by humans, where one was the killer and the other one the victim.

The double conception of rats - as scientific models and instruments in the lab as well as bearers of disease, grew during the 20th century. The hatred of rats was largely connected to the Western world and the emergence of the modern urban way of life. (Burt 2006, 10, 19, 117; Kalof 2007, 88.) During the 20th century, the main responsibility for killing rats was gradually taken from cats into human hands, and rats were faced with a fierce extermination campaign.

As the twentieth century progressed, colonial trade fell behind as the main context of disease-spreading. Now crowding and urbanization were put forward as the biggest threats to public health. Overcrowding was linked to lack of hygiene and, together with the fear of the masses, it made large numbers of people a threat in themselves. Densely populated areas were thought to attract large numbers of rats, so one way of dealing with the problem was to kill the rats. The rat was perceived as an atavism, a gothic representation of backwardness and filth. Though the spread of rats in fact followed from culture and urbanization, it was described as a threat to modern life. Like humans, rats seemed to appear in great numbers, as a swarm or a mass. This fear of the masses was thus channeled through the human relationship with rats.

The rat was thus continuously subject to extraordinary extermination measures. Rats were increasingly linked to common filth, bad hygiene, overcrowding and oldfashioned lifestyles. The war against them was led by the health authorities. The Swedish health authorities had been organized since the latter part of the 19th century (Sundin 2005, 24-25). The infrastructure for a broad hygienic reform was thus already in place when the authorities began their campaign against rats. In 1938 this endeavor in Sweden was crowned by the founding of the National institute for public health (Statens institut för folkhälsa). The Institute organized the work for public health. Combating rats and other vermin was considered an important measure to improve public health. Rats were continuously, discursively, connected to humans. In the advice published by The Royal Medical Board it was stated that the population of rats could be estimated by the number of people in a country (Råd och anvisningar angående åtgärder mot bostadsohyra samt råttor och möss 1934, 10). 
In the war on rats, research found a commercial market waiting to be exploited. Practices of exterminating rats thus grew from the market, innovations within research, and the modern welfare project. Newly founded companies efficiently used science to market their products. Medical doctors participated in the discussion about different innovations in the field of vermin extermination (Nilsson 1904; Bergman 1908). Commercial products were tested, their results widely discussed.

The authorities' efforts to improve public health soon prompted the emergence of commercial articles to promote the endeavor. Ratin was the most widely used method for large scale extermination of rats (Gray 2015, 51-52). In the official statistics of the activities of the veterinary services in the public sector, which was placed under the Swedish Royal Medical Board, the effect of Ratin was continuously evaluated. As a result, besides reporting the incidence of cattle disease, controlling the meat industry and slaughterhouses and the national export of meat, the Swedish authorities felt the need to report on the effects of a specific commercial method of rat extermination. This was partly due to the fact that the method involved the spreading of potentially dangerous germs. Yet, experiments with the marketable product were performed and the results published in official statistics by the veterinary services from 1917 to 1921 . The main interest was undoubtedly the effect of the extermination method on rat populations (Det civila veterinärväsendet 1917-1921). Rats were originally exterminated for their risk of spreading disease, but during the 20th century they became increasingly perceived as a threat merely because of their numbers.

\section{3 The relationality of the unwanted}

The domestication of the rat is connected to its role in science, as a laboratory rat. All pet rats are related to rats bred and used for experimentation. Simultaneously, as the Western project of exterminating the rat developed, the picture of the heroic laboratory rat, the martyr of science, emerged. During the 1960s there were several works published on the anatomy and biology of rats mirroring the increased use of the rat as a laboratory animal. The animal - the brown rat - has been a very popular scientific 'model' partly due to tradition, partly due to its convenience and reputation as disposable, partly to its biological resemblance to humans. Science and commercial interests worked together in the process. The attempts to develop a method for killing vermin was accompanied with experimental practice using animals - mainly rats. To establish the efficiency of the methods for killing them, rats themselves were exploited (Nilsson 1904, 3-4; Bergman 1908, 11-18; Sondén 1905, 5-10). In this context, the rat 
as laboratory animal was put into effect - the rat was both the object of the research and the method through which the research was conducted. Rats thus became threatening as uncontrollable spreaders of disease, and at the same time were understood as scientific models, helpful to humankind. Such action fully exploited the categorical liminality of the animal. As the animal welfare societies gained more influence, animal experimentation became increasingly challenged, portraying the rat as a victim rather than a threat.

The early animal welfare societies also debated the status of cats - as loathsome predators or pampered pets. Hunting organizations in Sweden had started to raise awareness about the threat straying cats and dogs posed for wildlife (Danell et al. 2016, 232), which influenced the work of animal welfare societies. Small birds had been cherished by animal advocates since the start of the movement. Therefore, cats maintained a liminal position oscillating between friend and foe in the view of Swedish animal welfare. Most hateful against cats in Sweden was the poet and artist Ivar Conradson (1884-1968) who in 1928 published a book about a sinister predator - the cat - and the naive animal protectors cuddling it (Conradson 1928).

There are other contexts, where the liminality of the animal is embedded in its seemingly straightforward categorization. Three countries within the European Network of Invasive Species, namely Denmark, Finland and the Netherlands, have entered the cat (Felis Catus) in their list of invasive species (NOBANIS, no date). The rat is, interestingly, not included. The reason that the cat is seen as invasive is that it is able, as a successful hunter, to become feral and is therefore perceived as a threat to animals that are considered wild (Rogers 2006). The wild animals perceived under threat are, again, small birds - not rats or even mice, still controlled by cats on farms. Here, the cat is unproblematically categorized as a domesticated animal, one that represents 'nonnature' compared to the wild animals under threat, and therefore embedded in human culture. Whereas feral cats proliferate around the world, the Nordic climate restricts the possibilities for a cat to survive on its own during winter, and animal welfare organizations have campaigned for decades against abandoning cats (Nieminen 2001).

The rat and the cat have been bound to each other by their position in society, but the developments in pet-keeping as well as the control of animal death have slowly transformed this connection. In the remainder of the paper, we will explore this transformation in the light of the experiental narratives. Their main focus is on cats, with examples of human-rat relations in the pet-keeping context. 


\section{The emerging pet}

\subsection{Agency and control}

The incentives for killing animals are embedded in the agency of the animal in different ways that highlight the liminality of the animal between categories. In the simplest sense, the actions of the animal are regarded as justifying the killing of the animal. In one example from the writing collection data, from the time of WWII, a cat has made the 'mistake' of eating food that was meant for humans and is therefore killed: "My father-in-law had killed poor Pekka, who had hoarded and eaten almost a whole piece of T-sausage" (SKS KRA. Pets 768-771. 2015. Female)1. Here, the animal is considered responsible for its own actions and has been punished, in this case killed, for its wrongdoings. This is in striking contrast to contemporary justifications for killing pets, visible in the following contemplations about cat euthanasia:

The decisions to euthanize have been the most difficult in my life. I have found comfort in the knowledge that the decisions have been right and justified and that their passing has been painless to the cats and relieved them from their ailments. Other people have expressed their condolences and sympathy. (SKS KRA. Pets 178-183. 2015. Female, b. 1951)

The transformations in the responsibility for killing have resulted in the killing itself becoming an act of care, if the animal is not seen to be able to continue life without excessive pain or suffering (Schuurman 2017). Initiated in the early years of the 20th century by animal welfare societies, the humane killing of pets has now become a norm and standard practice in urban pet-keeping. This is part of a wider change in the ways of relating to pet death, including its relocation to the spaces of vet clinics (Schuurman 2017), the practice of burying them at pet cemeteries (Schuurman \& Redmalm 2019), and the increasing acceptance of expressing grief for a lost pet (Redmalm 2015).

Rats have also been understood to have agency, but it has often been described as a threat. When the official extermination of rats in Sweden was launched, the advice given by the authorities was to plan the killing in such a way as to avoid the rat becoming suspicious. The actions were described as "controlling" the rats, that is, restricting their

1 References to the writing collection material are made as follows: SKS stands for Suomalaisen Kirjallisuuden Seura (Finnish Literature Society), KRA stands for Kansanrunousarkisto (Folklore Archives), Pets refer to the pet collection, numbers 768-771 stand for the page numbers of the narrative in collection, and 2015 is the year of collection. 
agency. In the 1920's the city of Stockholm provided 10000 crowns yearly for the purpose of killing rats (Regnér 1928, 3-4, 9). Continuously the rat was described as an independent agent, capable of threatening humans and their modern lifestyle. Rats were considered as invasive, being freeloaders outside their natural realm. Killing rats was therefore legitimate.

At the same time, cats were living as collaborators and companions to humans, a life that could not necessarily be considered safe. In agrarian times, cats moved freely although they 'belonged' to the house, epitomizing their liminal position between domestication and wildness but also enabling them to complete their task in killing rats. Their freedom often had severe consequences, and when cats died, they - or their 'ignorance', as in the examples below - were sometimes held responsible for the animal's fate:

During the spring Grandma's cat went its way, maybe crossed the river when the ice was still strong, and did not know how to come back in time. When the water is not frozen it is impossible for a cat to come back from the other shore. In the thirties, cats' lives were not as controlled as nowadays. It was very common for them to run away, get cat plague, or have an accident. Some cats died when they ate caustic soda at the washing place. I remember my playing mates crying for their cat that ate caustic soda. (SKS KRA. Pets 92-115. 2015. Female, b. 1931)

The quote illustrates how freedom and lack of control implicate a lack of responsibility for the animal's actions, creating space for animal agency. In another example, a cat had died after eating rat poison - ironically, the substance developed to replace the task assigned to the animal itself as a killer. Cats were understood to be responsible for their own lives, and it was up to them if they made fatal mistakes, as in the cases of cats eating poisonous substances. Fox and Gee (2019) argue that recent developments in petkeeping have increased the control of animals and, consequently, restricted possibilities for animal agency. For domesticated animals living within the sphere of human homes, life is often regulated spatially in ways that have a possibility of restricting their agency (Fox \& Gee 2019). It could be added that these restrictions also apply in many cases to relationality between species, even in the context of death.

Domestication, however, also implies control. In the case of cats, increasing control, resulting from their transformed status as urban pets, has given them safety - contrary to the efforts at controlling those rats that do not fall into the category of domesticated animals. Further, developments in the practices of care within the culture of pet-keeping have refined the ways of controlling animals for human purposes and, 
therefore, increased the degree of their domestication.

It is important to note that even in agrarian contexts, unrestricted animal agency resulting from lack of control did not rule out emotional attachment to individual animals, even if their movements were not as restricted as today (cf. Charles 2014). The death of animals was mourned even if they could not be kept safe from death at an early age. Such protection was simply not possible before the advances of veterinary practice, as noted by the narrator below, referring to events in the 1940s and 1950s:

\begin{abstract}
There was also grief and longing when one of the cats had kittens which were then sent to cats' heaven, although you didn't talk about cats' heaven at the time. [...] At the time cats were not neutered, at least I don't know about it, so they bred. Sometimes the females had two or three litters in one summer. (SKS KRA. Pets 351-361. 2015. Female, b. 1937)
\end{abstract}

Animals were cared for in ways that were possible at the time, even if this included the practice of "sending kittens to cats' heaven", resulting in "grief and longing". In this way, the recognition of animal agency portrays the animal as an independent, responsible actor, a non-human person or companion whom it is possible to mourn. Acknowledging agency can, however, also be used to distance the animal, as in the case of rats being exterminated. Killed rats were not mourned.

In these examples, animal agency can be understood to follow the dichotomy characteristic of Western thinking about animals: the animal as similar and a close companion to humans, or as a wild animal or pest, different from humans and at a distance from humans (Arluke \& Sanders 1996). In both cases, the animal can situationally be considered an independent actor - meaning that whether animal agency is acknowledged or not is not an inherent aspect of animal attitudes. Rather, it epitomizes how the animal, by its own actions, fluctuates between human-induced categories.

\title{
5.2 Killing as care
}

Domestication indicates that animals join a human household. Russell (2007, 33-36) thus proposes that animal domestication could be viewed as an extension of kinship to other species, especially as biology is no longer seen as the only base for kinship. In the case of cats, Rogers $(2006,142)$ suggests that due to their perceived independency and historical usefulness to humans in controlling rats, cats are easily treated as equal 
partners in a human-pet relationship. Understanding pets as kin also explains the emotions experienced in relation to the death of the pet, although mourning pets and expressing the grief in public is still not unanimously accepted (Redmalm 2015).

One aspect of kinship that can clearly be attributed to human-animal relations is care, both in the sense of emotion and responsibility, in feeling for the animal and in taking care of it (Milligan \& Wiles 2010, 741). The following quote illustrates the development in the practices of keeping cats and caring for them. Constructed as an autobiography of relations between the author's family and their cats over several decades, the narrative reveals how the position of the cats change, reflecting transformations in general attitudes concerning the care and death of pet cats:

At my childhood home in Ostrobothnia we often had a pet cat, no dogs. The cats came from somewhere or were given by someone. They also disappeared in their own time. They came in to eat or to knock around, otherwise they went their ways outside. [...] A brownish yellow kitten arrived from somewhere in 1976. He was called Mikki. He was killed in an accident in Virrat in the summer, hit by a car wheel and died. [...] Another one, brownish orange with stripes, the gentle Tupu, arrived from somewhere. She was very sweet, the children petted her. My husband said she was a stupid cat, couldn't find the way home. She disappeared in winter 1982. [...] Väinö was also with us at the summer cottage in Virrat. At home in Kotka he disappeared, we waited in vain and called and looked. Then a rumour started spreading that there was a cat hater, killing cats [...]. Topi lived until over 10 years old, after which he got ailments and could not jump on to the fence anymore, or walk properly. Finally my husband had him euthanized and cremated. (SKS KRA. Pets 908-909. 2015. Female)

The ways in which care, in both senses of the word, the emotion and the practice, has become central in pet-keeping, is epitomised in the following description of cat euthanasia in the 2000s: "I held my little cat Nekku in my lap the whole time, talked to her and told her how much I loved her, and she was able to fall asleep in my lap" (SKS KRA. Pets 366-369. 2015. Female). What is especially interesting is how emotions are involved as drivers for change in how the cat has become a pet. In the following example, kittens are at first killed as unwanted pets, but during the process, the killing becomes emotionally unbearable because of the emerging understanding of the cat as a pet with a right to live: 
The first one I put on the list to be euthanized was the black kitten that Lilli had first brought in. The next one would have been the piebald one. The first euthanasia had been enough for my sensitive husband, and the rest were spared. (SKS KRA. Pets 822-839. 2015. Female, b. 1949)

Liminal fluctuations also concern the different positions of animals in the category of pet. When rats are kept as pets, they are often not placed in the same position as cats or dogs, animals that are popular in families with small children. Instead, rats are often kept by teenagers and young adults, meaning that these pets become embedded in identity construction and part of growing up for their owners (Irvine 2004). The death of these pet rats therefore signifies the process of moving out from the parental home and getting on with one's own life. The following excerpt by an author who moved out at the time described, is an example of such a process:

\footnotetext{
My first rat Rocky was already old (3,5 years) around the mid-1990s. He was not well anymore, so I made the decision to have him euthanised at the vet clinic, painlessly and calmly. I wept for Rocky and missed him too, but I was still proud of myself for being able to do it. (SKS KRA. Pets 643-653. 2015. Female)
}

Another rat owner describes the experience of having had pet rats as a teenager and, as a young adult, contemplates her feelings concerning their death: "I think my own age also influenced the grief for the death of a pet rat. I probably handled the issue a bit differently as a teenager than as an adult" (SKS KRA. Pets 779-785. 2015. Female).

The examples show that although the rat has become domesticated to the extent of being a pet, it is still liminally positioned, to the fringes of family life, as a companion for teenagers whose very own status between child and adult can be considered liminal. Despite all the differences in the position and mutual relations between cats and rats, the ways in which they remain marginalised are still very similar. Their position as loved pets has not erased the adverse feelings felt towards them nor the fact that considerable numbers of both species are killed when found running free - even if cats may first be taken to shelters for possible adoption, many never find a new home. At the same time, the practice of killing as care means that most pet cats and rats are still killed by humans - only the contexts and the ways of killing have changed. Ultimately, humans never give up their possibility to kill the animal, regardless of whether they love it or hate it. 


\section{Conclusions}

In the beginning of this paper, we set out to explore the ways in which transformations in human-animal relationality are visible in the norms and practices regarding the killing of animals, in this case rats and cats, with a special focus on liminality and domestication. These two aspects are interrelated; at the center of the conception of liminality for both the rat and the cat is the symbolic boundary-crossing aspect of the animal, epitomised in their spatially and temporally varying degrees of domestication. Transformations in their liminal position and their domestication has, consequently, changed the mutual relationship between cats and rats: cats have no duty nor chance to kill rats anymore, whereas the inhumane killing of rats only applies to those individuals still categorized as 'wild'.

The rat is a creature inhabiting the same space as humans and it seems not to accept the privileged position of humans in relation to other species. It resists control and persists in a human-like life, shamelessly eating our food, occupying our space. The mid-20th century interest in (the extermination of) the rat is an animal mirror of the post-war tension between civilization and instinct. The extermination of rats is also certainly one of the practices following of post war social reformism. Organized attempts to manage rat populations seem connected to the fear of the back side of urban life, but they also reflect more complex relational changes in the embodied relationship between the cat, gradually severed by urbanization. Modernizing the city meant trying to control its rats, but it also brought about new practices in cat-keeping, freeing the rodent from its age-old foe. Temporal and spatial changes from the rural farmyard to the urban home thus altered the position of the cat in relation to humans: the independent actor with a task of killing rodents became a pet and a family member.

The rat that has no 'natural' 'wild' habitat is a truly liminal inhabitant of natureculture (Haraway 2008); it does not leave nature to scavenge culture - instead, it seems to come with culture, representing its downsides of overcrowding and urbanization. Along with the cat, it has entered the realm of urban pet-keeping. Even as a pet, the rat remains in the fringes of pet-keeping culture, as an 'alternative' pet (Fox 2006) or the apt companion for the teenager, building their distance to their childhood family. For the cat, the acceptance of expressing emotions enforces its recently emerged category as primarily a pet, a sentient being capable of feeling and in need of care. It is not defined as killable in the same way as before, but instead, having a cat euthanised has become as an act of care, based on assessments of the cat's wellbeing.

The redefined place of the rat and the cat through the cultural process of 
domestication affect their categorization as animals, and life in the increasingly closed space of the human home has extended their domestication. The fluidity of the rat challenges its categorization, but it is also a characteristic which makes the animal modern (Wischermann et al. 2018, 5). The semi-wild agency of the cat has been replaced by care and control of the domesticated feline pet. This turns the focus to the question put forward by Fox and Gee (2019): to what extent are pets allowed agency of their own? Or, to what extent is the agency of the animal a sign of the liminality of its domestication? Perhaps the liminality of the animal is its most provoking quality?

Cats and rats share the position of being simultaneously hated and cared for. These animals occupy a liminal position but are themselves liminal, that is, by their agency they transcend the categories that humans place them in. It is therefore the liminality of the cat and the rat which poses challenges to their categorization and, subsequently makes humans restrict their agency by different management and care practices. As stated by Foster \& McCabe $(2015,48)$, liminality can be 'simultaneously destructive and constructive', and for the animals whose fate is tied to their fluctuation between different positions this is very true.

The ways in which human attitudes to animals have consequences for their lives, depend on three aspects that define the degree of their domestication: firstly, the extent to which they have agency and whether their agency is recognized, secondly, their dependence of human care and, thirdly, the level and quality of control of the animals. Animal agency is not a concept that always works for the benefit of the animal in promoting its care, although this is increasingly evident in the case of beloved pets. In the cases where agency is awarded to animals considered pests, however, it is used to justify their control. Both instances are visible in the practices of killing animals, as we have shown in this paper, through the analysis of the transforming societal position of rats and cats. As a result of this transformation, both these animals have increasingly entered the current realm of relational ethics regarding the treatment of animals, characterized in the practices of killing them responsibly.

Finally, the study provides an example of different multispecies relational networks and the transformations of different species within these networks, brought about by developments in human attitudes to these animals and in the practices of care, control and killing - practices that largely define how humans manage their encounters with other species. The liminal positions occupied by rats and cats render them dynamic and provoking, complicating the practices of killing them. 


\section{REFERENCES}

Annual report of the Swedish women's association for the protection of animals, 1888.

Annual report of the Swedish women's association for the protection of animals, 1900.

Annual report of the Swedish women's association for the protection of animals, 1902.

Annual report of the Swedish women's association for the protection of animals, 1905.

Arluke, A. and Sanders, C. R. 1996. Regarding Animals. Philadelphia: Temple University Press.

Benedictow, O. J. 2010. What Disease was Plague? Leiden: Brill.

Bergman, A. M. 1908. "Om tvenne utrotningsmedel för råttor, bakteriekulturerna Ratts och Ratin. Speech given at Lunds läkaresällskap 28/4-1908." Särtryck ur Allmänna Svenska Läkaretidningen 24.

Beumer, K. 2014. "Catching the rat: understanding multiple and contradictory human-rat relations as situated practices." Society \& Animals, 22(1), 8-25.

Bjärvall, A. \& Ullström, S. 1985. Däggdjur: alla Europas arter. Stockholm: Wahlström \& Widstrand.

Broberg, G. 2004. Kattens historia: Sverige speglat i djurets öga. Stockholm: Atlantis.

Bulliet, R. W. 2005. Hunters, Herders, and Hamburgers: The Past and Future of Human-Animal Relationships. New York: Columbia University Press.

Burt, J. 2006. Rat. London: Reaktion.

Cartmill, M. 1993. View to a Death in the Morning: Nature of Hunting through History. Cambridge, Mass.: Harvard University Press.

Cassidy, R. 2007. "Introduction: domestication reconsidered." In R. Cassidy \& M. H. Mullin (eds.), Where the Wild Things are Now: Domestication Reconsidered. Oxford: Berg, 1-25.

Charles, N. 2014. "'Animals just love you as you are': experiencing kinship across the species barrier." Sociology, 48(4), 715-730.

Charles, N. \& Davies, C. A. 2011. "My family and other animals: Pets as kin." In B. Carter \& N. Charles (eds.), Human and other animals: Critical perspectives. Basingstoke: Palgrave Macmillan, 69-92.

Crist, E. 1999. Images of Animals. Anthropomorphism and Animal Mind. Philadelphia: Temple University Press.

Conradson, I. 1928. Om djur och om människan och djurvärlden. Stockholm:_Seelig \& Co. 
Crowley, S. L., Hinchliffe, S. \& McDonald, R. A. 2018. "Killing squirrels: Exploring motivations and practices of lethal wildlife management." Environment and Planning E: Nature and Space, 1(1-2), 120-143.

Danell, K., Bergström, R., Mattsson, L. \& Sörlin, S. (eds.) 2016. Jaktens historia $i$ Sverige: vilt, människa, samhälle, kultur. Stockholm: Liber.

Despret, V. 2016. What would Animals Say if We Asked the Right Questions? Minneapolis, MN: University of Minnesota Press.

Dirke, K. 2000. De Värnlösas vänner. Den svenska djurskyddsrörelsen 1875-1920. Stockholm: Almqvist \& Wiksell.

Djurvännen 8, 1880.

Djurvännen 5, 1887.

Djurvännen 4, 1888.

Djurvännernas Tidning 4, 1890.

Echenberg, M. J. 2007. Plague Ports: The Global Urban Impact of Bubonic Plague, 1894-1901. New York: New York University Press.

Foster, C., \& McCabe, S. 2015. "The role of liminality in residential activity camps." Tourist Studies, 15, 46-64.

Fox, R. 2006. "Animal behaviours, post-human lives: everyday negotiations of the animal-human divide in pet-keeping." Social \& Cultural Geography, 7(4), 525-537.

Fox, R. \& Gee, N. R. 2019. "Great expectations: changing social, spatial and emotional understandings of the companion animal-human relationship." Social and Cultural Geography, 20(1), 43-63.

Franklin, A. \& Schuurman, N. 2019. "Aging animal bodies: horse retirement yards as relational spaces of liminality, dwelling and negotiation." Social \& Cultural Geography, 20(7), 918-937.

Gezelius, K. J. 1911. "Anordningarna till utrotande af råttor ombord på fartyg i Hamburgs hamn." In Om åtgärder till utrotande af råttor ombord å fartyg. Meddelanden från Kungliga Medicinalstyrelsen N:o 16.

Gray, R. 2015. The Pest Detectives. The Definitive History of Rentokil. Petersfield: Harriman House.

Haraway, D. 2008. When Species Meet. Minneapolis: University of Minnesota Press.

Herman, A. \& Yarwood, R. 2014. "From services to civilian: The geographies of veterans' post-military lives." Geoforum, 53, 41-50.

Holmberg, T. 2015. Urban Animals: Crowding in Zoocities. London: Routledge. 
Ingold, T. 1994. "From trust to domination: An alternative history of human-animal relations." In A. Manning \& J. A. Serpell (eds.), Animals and Human Societies: Changing Perspectives. London: Routledge, 1-22.

Ishiyama, S. \& Brecht, M. 2016. "Neural correlates of ticklishness in the rat somatosensory cortex." Science, 354(6313), 757-760.

Jerolmack, C. 2008. "How pigeons became rats: The cultural-spatial logic of problem animals." Social Problems, 55(1), 72-94.

Kalof, L. 2007. Looking at Animals in Human History. London: Reaktion.

Kean, H. 2017. The Great Cat \& Dog Massacre. The Real Story of World War II's Unknown Tragedy. Chicago, IL: University of Chicago Press.

Latvala, P. \& Laurén, K. 2013. "The sensitive interpretation of emotions: methodological perspectives on studying meanings in oral history texts." In Frog \& P. Latvala with H. F. Leslie (eds.), Approaching Methodology. Helsinki: Finnish Academy of Science and Letters, 249-266.

Leach, E. 1964. "Anthropological aspects of language: animal categories and verbal abuse." In E. H. Lenneberg (ed.) New Directions in the Study of Language. Cambridge MA: MIT Press, 23-63.

Leach, H. 2007. "Selection and the unforeseen consequences of domestication." In R. Cassidy \& M. H. Mullin (eds.), Where the Wild Things are Now: Domestication Reconsidered. Oxford: Berg, 71-100.

Leinonen, R.-M. 2013. Palvelijasta terapeutiksi. Ihmisen ja hevosen suhteen muuttuvat kulttuuriset mallit Suomessa. Oulu: University of Oulu.

Marvin, G. 2006. "Wild Killing; Contesting the Animal in Hunting." In The Animal Studies Group (ed.) Killing animals. Urbana: University of Illinois Press, 10-29.

McFarland, S. E. \& Hediger, R. 2009. "Approaching the agency of other animals: An introduction." In S. E. McFarland \& R. Hediger (eds.), Animals and Agency. An Interdisciplinary Exploration. Leiden: Brill, 1-20.

Milligan, C. \& Wiles, J. 2010. "Landscapes of care." Progress in Human Geography, $34(6), 736-754$.

Nieminen, H. 2001. Sata vuotta eläinten puolesta. Kertomus Suomen Eläinsuojeluyhdistyksen toiminnasta 1901-2001. Helsinki: Suomen Eläinsuojeluyhdistys.

Nilsson, G. 1904. Claytons apparat för desinfektion af fartyg och Nochts koloxidapparat för dödande af råttor. Stockholm.

NOBANIS. Felis catus (Felidae, Mammals). European Network of Invasive Species. https://www.nobanis.org/species-info/?taxald=2885. Accessed October 31, 2019. 
Power, E. 2008. "Furry families: making a human-dog family through home." Social and Cultural Geography, 9(5), 535-555.

Power, E. 2012. "Domestication and the dog: embodying home." Area 44(3), 371378.

Redmalm, D. 2015. "Pet grief: when is nonhuman life grievable?" The Sociological Review, 63(1), 19-35.

Redmalm, D. 2019. "To make pets live, and to let them die: The biopolitics of pet keeping." In T. Holmberg, A. Jonsson \& F. Palm, (eds.), Death Matters. Cham: Palgrave Macmillan, 241-263.

Regnér, C. O. 1928. Råd och anvisningar för utrotande av råttor. Stockholm.

Reinhold, A. S., Sanguinetti-Scheck, J. I., Hartmann, K. \& Brecht, M. 2019. "Behavioral and neural correlates of hide-and-seek in rats." Science, 365(6458), 1180-1183.

Ritvo, H. 2010. Noble Cows and Hybrid Zebras: Essays on Animals and History. Charlottesville: University of Virginia Press.

Rogers, K. M. 2006. Cat. London: Reaktion.

Russell, N. 2007. "The domestication of anthropology." In R. Cassidy \& M. H. Mullin (eds.), Where the Wild Things are Now: Domestication Reconsidered. Oxford: Berg, 27-47.

Råd och anvisningar angående åtgärder mot bostadsohyra samt råttor och möss, 1934. Stockholm: Nord. bokh.

Schuurman, N. 2017. "Performing good death at the veterinary clinic: experiences of pet euthanasia in Finland." Area, 49(2), 208-214.

Schuurman, N. \& Redmalm, D. 2019. "Transgressing boundaries of grievability: Ambiguous emotions at pet cemeteries." Emotion, Space and Society 31, 32-40.

Schipani, S. 2019. "The history of the lab rat is full of scientific triumphs and ethical quandaries." Smithsonian.com. https://www.smithsonianmag.com/sciencenature/history-lab-rat-scientific-triumphs-ethical-quandaries-180971533/. February 27.

Sondén, K. [G. Anders] 1905. Studier rörande metoder att utrota skeppsråttor. Stockholm.

Statista 2019. Number of pet animals in European Union in 2018 , by animal type (in 1000s). https://www.statista.com/statistics/515010/pet-population-europeanunion-eu-by-animal/. Accessed October 30, 2019.

Sundin, J. (ed.) 2005. Svenska folkets hälsa i historiskt perspektiv. Stockholm: Statens folkhälsoinstitut. 
Svärd, P.-A. 2015. Problem Animals: A Critical Genealogy of Animal Cruelty and Animal Welfare in Swedish Politics 1844-1944. Stockholm: Stockholms universitet.

Whatmore, S. \& Thorne, L. 1998. "Wild(er)ness: reconfiguring the geographies of wildlife." Transactions of the Institute of British Geographers, 23(4), 435-454.

Vieraslajit.fi. Kissa (Felis catus). https://www.vieraslajit.fi/lajit/MX.53004/show. Accessed October 31, 2019.

Wischermann, C., Steinbrecher, A. \& Howell, P. (eds.) 2018. Animal History in the Modern City: Exploring Liminality. London: Bloomsbury. 